\title{
(Re)Confirming the Conventions - An Ontology of the Olfactory
}

\author{
Helen Paris
}

\begin{abstract}
Dans son article, Helen Paris explore le rôle de l'odorat dans l'interprétation en direct, la capacité de l'odorat de déclencher les souvenirs et les émotions, et le très insoupçonné, mais néanmoins incroyable impact de l'odorat sur les processus cognitifs et reproductifs. À une époque de plus en plus médiatisée, de plus en plus virtuelle, et dans laquelle la communication est de plus en plus numérique ou électronique, ce projet s'intéresse particulièrement au viscéral. L'odeur, comme l'interprétation en direct, possède une qualité éphémère, une présence insaisissable. Pour Helen Paris, l'odorat trouve son emplacement naturel dans le monde de l'interprétation en direct.
\end{abstract}

Live performance engages the spectator in a same-time, same-space reality with performer and performance, a phenomenon referred to by Walter Benjamin as a "cult" event, ephemeral in nature. Contemporary digital and screen arts have engendered a new body of discourse around increasingly mediatised - and increasingly reproducible - performances enabled by new technologies. This article examines the unique aspects of live performance, with which technology cannot (yet) compete, and posits an "ontology of the olfactory," citing the sense of smell as an emotive and powerful sense for both performer and audience. While I am not interested in prioritising live over mediated - indeed I am drawn to find a more reciprocal, even symbiotic relationship between the two - I am interested, as an artist who works within both live and mediated formats, in exploring the visceral in the age of the virtual.

The human sense of smell, linked to the cognitive centers in the brain (Corbin 7), is a powerful evocation of memory: "Smell may be to emotion what sight or hearing is to cognition" (Engen 3). It is the emotive impact of smell that I am most interested in exploring, particularly with respect to its impact when used in live performance. "The perception of smell, thus, consists not only of the sensation of the odours themselves, but of the experiences and emotions associated with them" (Classen et al. 2). Smells 
can be highly evocative, conjuring up the vivid memory of associated events and places, even from remote childhood.

\section{Smell in Random Acts of Memory}

Over the years, I have used the sense of smell in live work both as a tool with which to generate emotionally charged and viscerally engaged performances, and as a prompt to personalised interpretations sensed by the audience in response to that work. For example, Sniffing the Marigolds, which premiered at the Institute of Contemporary Arts in London in 1995, was informed by the scientific fact that smell can induce instinctive, physical reactions in the body and act as a potent evocation of experience / memory. Smell was used in the piece as a catalyst for releasing body memory, acting as a stimulus for producing the work. In the performance itself, the body is affected by and physically responds to smell and, for the audience, there is a real presence of smell (flowers, earth). In the terms of Barbra Egervary, "Paris extends the range of languages at the performer's disposal. She incorporates film and video footage, projection, movement and choreography, smell and taste into her performances, using every means of communication at the performer's disposal. ... There is a totality, a wholeness, a truth and honesty in Paris's work, an overarching representation of experience" (34).

In this discussion, I take the performance Random Acts of Memory, created and performed by artist Leslie Hill and myself at the Institute for Studies in the Arts, Arizona State University (1998) as case study. Random Acts of Memory investigated the relationship between digital and synaptic memory, between replication and interpretation, between live and prerecorded, between mediated and 'raw,' and between high-tech and lowtech moments and sensibilities. It was a performative exploration of the visceral in the age of the virtual, achieved through full employment of the visceral, live presence, the sensory - sometimes amplified, repeated, manipulated, distorted and/or obliterated by technological apparatus. According to theatre critic Philip Auslander,

One of the main conventional explanations advanced for the continued appeal of live performance is that it offers a fuller sensory experience than mediatized performances. Whereas mediatized representations appeal primarily to the visual and auditory senses, live performances engage all the senses, including the olfactory, tactile, somatic, and kinesthetic. (55) 
Auslander passes swiftly over this area, going on without elucidation or example to conclude,

I would argue that this is not the case, that these other senses are engaged by mediatized performances. It certainly can be the case that live performance engages the senses differently than mediatized representations, but a difference in kind is not the same thing as a difference in magnitude of sensory experience. (55)

As a performer, I posit that the "difference" Auslander mentions does in fact have a substantial effect on the magnitude of sensual experience proffered in live performance. The sense of smell is a case in point.

In Random Acts of Memory smell is the first real presence in the auditorium. The auditorium is filled with the intermingling scents of licorice and pumpkin, into which the audience enter. Pumpkin has been found in scientific research to be a smell which arouses men; for women, the smell is licorice. Licorice sweets are handed to all the female audience members as they enter the theatre space. Pumpkin pie has been cooked in the auditorium prior to the show and pumpkin spice scattered underneath the chairs. Amelia Jones describes Maureen Conner's 1991 piece, entitled The Senses, as probing "the unlocatable limit between the body and the world that Merleau Ponty explored as flesh of the world, marking this flesh as specifically (but not inherently) gendered and its embodied experience as always highly charged, sexual, and - by definition - intersubjective" (210). In addition to the smells that greet the audience as they enter the theatre space, a sound recording of a Radio 4 program loops quietly in the background on the subject of smell. Within the aroma-filled auditorium the performance has already begun. One of the performers, Helen, picks up an antimacassar and inhales the lingering odor of the cloth. Part of the cloth has been worn away and Helen starts to speak through the worn bit in the antimacassar. Suddenly Helen's memory becomes clear, obviously triggered by the smell from the material. The sound of football score results fades in, and drones on in the background as she is transported by the memory back to its site, a moment in her childhood:

Helen: This smells just like my grandparents' house. My grandmother had these antimacassars on the back of all the armchairs. Their whole house smelt like their chairs. You could bury your face in those 
armchairs - deep in the crevices between the arm and the seat and smell the whole house. We went there every Sunday. There were wooden bowls of toffee on the table and football all afternoon.

\section{"Westbromich Albion: 1 Manchester United: Nil}

Bristol Rovers: 2 Liverpool: 1"

This was on my grandfather's chair - you can see where my grandfather's head wore away the material. He sat in the chair to the right of the fireplace as you came in. He died in that chair. The cat from next door was still asleep on his lap. He was wearing his blue and white striped apron still on from cooking the dinner. It was New Year's Eve. I found him. I came in to see if he wanted to go for a drink. "Granddad, do you want to go for a drink?" He was dead in the chair.

“Crystal Palace: 1 Queens Park Rangers: 1

White Hart Lane - Huddersfield: Match postponed"

Insofar as it stimulates the performer to speak, smell activates the performance. The sound effect of the football scores in the background emphasises that the performer has been transported back to the time she speaks of, and because the audience hear it too, so have they. The memories released in the piece are central to the ontology of the performance itself. Random Acts of Memory plunges performers and audiences into an environment where smell serves as a strong, emotive evoker of memory stories, providing the performers with segues and transitions between the action as smells they remember or sense on the set jog their memories.

The whole notion of authenticity engendered by real olfactory encounter is a recurrent theme within Random Acts of Memory. One moment, true stories triggered by real circumstances are related and, the next moment, characters lie about the truth or the ownership of those stories. For example, the story about the death of the grandfather was evoked by placing the antimacassar over my face at one point in the rehearsal process and the smell of the fabric did actually trigger the memory of my grandfather. Although the story about the grandfather is authentic in that it was literally triggered by the smell on the antimacassar, when the story is repeated in the performance, the audience discovers that some details are not exactly true: 
Leslie: Could you repeat that story about your grandfather, but this time cheat your face towards the camera a little?

Helen: ... This was on my grandfather's chair - you can see where my grandfather's head wore away the material. He sat in the chair to the right of the fireplace as you came in. He died in that chair. The cat from next door was still asleep on his lap. He was wearing his blue and white striped apron still on from cooking the dinner. It was New Year's Eve. Uncle Michael and cousin David found him. They came in to see if he wanted to go for a drink. I know I said before that it was me that found him, but it wasn't. It wasn't me. It was in fact my Uncle Michael and cousin David. So I don't know why I said that. It's just that sometimes I see it that way. Sometimes I remember it like that.

When Helen is asked to repeat the story of her grandfather, the audience listens with half an ear - until she comes to the ending which is now different. Given that it is already part of their own 'performance memory,' they assume they know what is coming and are, therefore, caught out when they pick up on the change in the second version. In this moment, the audience experience their own memory process.

Throughout Random Acts of Memory, an intermingling of stories coincides with the intermingling of smells. The smells are always authentic and the stories true but the ownership of the stories, of the memories, is questionable. For example, after telling the story about her own dead grandfather, Helen gets up from the chaise longue and goes over to the bar cart. Picking up a shaving lotion bottle that was on the 'memory game' tray she unscrews it, inhales deeply. She then proceeds to claim a story about Leslie's grandfather as if it is her own, and the audience are momentarily tricked.

Helen picks up shaving lotion bottle. Frozen image cuts to live feed of Helen at bar cart.

Helen: When my grandfather died, he left me his shaving lotion bottle collection. Which was odd, really. Considering that he had eight grandsons. I suppose it was because the shaving lotion came in bottles shaped like cars and when I was little I used to love playing with them on the carpet. 
Leslie crosses to cart and takes bottle from Helen while video source switches from live feed to prerecorded section: Leslie standing in front of bar cart [repeating the words we have just heard].

Next, Helen begins telling a story evoked by smell as if it has jogged her memory. It becomes apparent, however, that she can only remember the story as long as the smell is present for her and, thus, tells it on long intakes of breath. At one point, as Helen inhales, Leslie dabs her grandfather's shaving lotion onto the antimacassar, which has previously been associated with the smell of Helen's grandfather, as if erasing Helen's olfactory memory in order to replace it with her own.

Helen: Breath. The thing with smell is that you remember the whole smell - not like half remembering a face that was definitely the pantry I can feel the light coming in the tiny side window and the biscuits kept in the yellow and blue Tupperware boxes so all you can smell is the Tupperware and all you can taste is the Tupperware. Breath. There is this man who works on an exhibition called the London Experience and he has to create the smell of London in the old days that was father's suede jacket smoke city air leather and him coming home every Friday in his dark suit with sweets in his brown leather briefcase. Lime chocolates for my sister and black licorice for me. Breath. So that is his job and it's not just the smell of food and street fumes that he recreates he even does the great plague apparently a dead pig smells just like a human corpse that was the building we used to have history in it took me ages to realize that was the smell of a damp building rather than the smell of history or the smell of the history teacher. Breath. Once a week a group of old people come to the exhibition on a trip down memory lane as he takes them past recreations of old fireplaces and the smell of the blacking reminds them of their mothers there is a smell that has always scared me I don't even know why I don't know what it is I can't define it but sometimes without warning I can suddenly smell it. Breath. The smell of Brilliantine reminds them of fast boys or was it more that the boys who wore that had reached the age when they were interested in girls and then they wonder what came first the hair wax or the sex and then they all go back home the smell that most excites men is pumpkin pie whereas women respond more readily to licorice.... 
The duration of the story Helen is telling literally depends on breathing in the smells which trigger her memories.

Random Acts of Memory makes clear not only the ability of smell to trigger memories but also the very function of synaptic impulses within the brain. In the performance, a direct connection is made between these areas of smell, the brain and memory. Pouring the shaving lotion on to the antimacassar, for example, Leslie rubs the smell, the memory, the presence of her grandfather into the silver chrome table, as if enervating the chilly metal techno environment. When she has covered the entire surface, she lights a cigar, inhales and then slowly exhales a fog of smoke over the table three or four times until the smoke has touched the entire surface. The cigar smoke and the after-shave evoke personal memories of her grandfather which are interwoven with comments on RAM and synaptic memory, as if all share a homogenous relationship:

Leslie: One cell, one memory may not be exactly the way things work, but it seems to be the first way that people think about the problem of locating memories in cells. Even if you aren't familiar with how computers store data, the take home message of most introductions to the brain is that there are pigeon-hole memories - highly specialized inter-neurons, the firing of which might constitute an item's memory evocation. On the perceptual side of neurophysiology, we call it the grandmother's face cell (a neuron that may fire only once a year, at Christmas dinner). Obviously, my father has many more memories of my grandfather than I do and I've come to realize that this is the reason I liked my grandfather better. Recall, of course, is not the same thing as recognition, and my grandfather never gave my father the. recognition he deserved. No present technology provides an analogy to help us think about the problem of associative memory and distortion. He never forgave him, but he was holding his hand when he died.

The personal, emotive and poignant memories triggered by the smell of the aftershave are intertwined seamlessly with ideas surrounding the memory of the machine and with precise descriptions of what is happening in the brain at the very moment of remembering and telling the stories (similar to when the audience experienced their own memory process as Helen repeated the story of her grandfather). Here, at the very moment 
when the performer is saying these lines and her brain is following the functions of which she speaks, her outside presence is being 'remembered,' recorded, and projected by the camera. The seamless interflow between smell, the synaptic functions in the brain and memory is expounded by Engen when he states that

The neurological impulses in the olfactory system seem to have a more direct route from the receptors to the brain. They have direct access to the limbic system and then to the cerebral hemispheres. Olfactory information may therefore be processed more quickly and with less editing than visual and auditory information. Odor memory may last longer because of a larger number of connections to different parts of the brain that may make possible more associations. (109)

In Random Acts of Memory smell triggers thought and memory and, in a sense, highlights the moments when the performers interact on their most honest, personal levels. Certainly smell engenders deeper and more emotive reactions in the performers than the plethora of audio and visual stimwhich surround them.

\section{Shared Ontologies: Smell and Performance}

As I argued above, a direct connection can be made between the synaptic function of the brain and odor memory. Not only is smell a distinct and emotive dynamic, unique to live work, but it is also like performance because of its ephemeral, unrecordable nature. As Alan Read writes of the olfactory, "it is frankly difficult to deal with, notoriously hard to pin down, and of interest only to an analysis which begins from the everyday realm in which it plays such as important yet unthought part" (121). And in the terms of Peggy Phelan, "Without a copy, live performance plunges into visibility - and disappears into memory, into the realm of invisibility and the unconscious where it eludes regulation and control" (148). I wish to explore Phelan's statement further, particularly her idea that performance is recordable only within memory, by comparing the ontology of performance to that of smell.

In Aroma: The Cultural History of Smell, the authors state that odours cannot be recorded: "There is no effective way of either capturing scents or storing them over time. In the realm of olfaction, we must make do with descriptions and recollections" (3). The mortality and ephemerality of 
smell is emphasized at the end of Random Acts of Memory when the electricity has been switched off and each performer is illuminated only by the flame from a match. Leslie refers back to the bottles of shaving cologne bequeathed to her by her grandfather, stating that, "The devastating thing about my inheritance is that it smells like him, but it doesn't smell of him." Compare this notion that smell cannot be preserved with Phelan's definition of the unmarked, ephemeral and undocumentable nature of performance:

Performance's only life is in the present. Performance cannot be saved, recorded, documented, or otherwise participate in the circulation of representation or representations: once it does so, it becomes something other than performance. To the degree that performance attempts to enter the economy of reproduction it betrays and lessens the promise of its own ontology. (46)

Phelan's statement, one of the most frequently cited within academic and artistic fields, and certainly one of the statements that seems to be most problematic for Auslander, recalls Read's statement about the impermanence of smell. Both performance and smell, then, reflect an intangibility, an ungraspability which defines their very nature. Vroon writes that

Our terminology for describing smells is generally meager or inadequate, due to our neural architecture. The parts of the brain that are closely involved in the use of language have few direct links with the olfactory system. Because consciousness and the use of language are closely connected, it is understandable why olfactory information plays a part mainly on an unconscious level. (110-11)

Just as live performance cannot be captured and reproduced without the documentation changing it, so smell and the memories it evokes are of the moment. Smells can, however, be remembered long after the initial sensation has been experienced. Like performance, smell can live on in the memory, unlocking a personal history, occupying "les lieux de mémoire." I define this phenomenon as "body memory," locating it within the whole body (Classen et al. 100). 


\section{Artifical Olfaction}

The notion of the intermingling of truth and falsehoods, of real smells in a mediated environment, leads me to another area concerning smell and its relationship to live and mediated performance, namely synthetic or artificial smells. "Today's synthetic scents ... are evocative of things which are not there, of presences which are absent: we have floral-scented perfumes which were never exhaled by a flower, fruit-flavored drinks with not a drop of fruit juice in them" (Classen et al. 205). Similarly, for Auslander, "in terms of the cultural economy the live actors are only pale reflections of the mediatised representations that dominate the cultural landscape" (37).

Synthetic smell is certainly at the heart of the commercial and economic market. Can mediated performance be said to be like the smell which has been "artificially created"? In Aroma: The Cultural History of Smell, Classen et al. cite Jean Baudrillard in reference to artificial smells and flavors stating that "the world has come to be "completely catalogued and analyzed and then artificially revived as though real." In the same way, artificial flavors are created "by the synthetic reproduction of individual flavor notes present in the original" (204). For Benjamin, questions of authenticity and presence are bound up in "aura," which he defines using the example of nature, stating that aura is based on

The desire of contemporary masses to bring things "closer" spatially and humanly, which is just as ardent as their bent toward overcoming the uniqueness of every reality by accepting its reproduction. Every day the urge grows stronger to get hold of an object at very close range by way of its likeness, its reproduction. (223)

Does odour/odor/aroma, however one writes it, produce aura? Does the object pried from its shell, its aura destroyed, lose its smell, which gave it a sense of self, of place, of identity? Does odour, like aura, work best at a distance? "The best place to smell perfume is at a distance from its owner" (Read 122).

At the end of a section entitled "Smell: The Postmodern Sense?" Classen et al. write,

In our postmodern world smell is often a notable ... absence. Odours are suppressed in public places, there are no smells on television, the world of computers is odour free, and so on. This olfactory "silence" 
notwithstanding, smell would seem to share many of the traits commonly attributed to postmodernity... The past irrelevant, the future uncertain, postmodernity is a culture of "now," a pastiche of styles and genres which exists in an eternal present. Postmodernity is also a culture of imitations and simulations, where copies predominate over originals and images over substance. (203)

All these notions of smell can be applied directly to the performance of Random Acts of Memory. In terms of the proposition that in postmodern culture "copies predominate over originals," it is interesting to note that the experience of performing with technology oftentimes left Leslie Hill and myself, as performers in Random Acts of Memory, feeling all the more messy, uncontrolled; we became the unprogrammed element of our media performance, particularly in terms of the clones. One of the reasons that we made the decision to include this smell/breath session, cited above, was to emphasise this visceral, physical presence, thereby asserting control through emphasising the unprogrammable, uncontrollable elements. For example, the visceral energy of the performer as she performs the smell/breath text, each smell allowing her only one breath, is juxtaposed with the cold, chrome set, the steely surveillance of the digital camera, the glare of the video monitors and projection screens. The performer forces the ends of the sentences out from the last breath left in her lungs; the sound coming from deep inside, uncontrolled, jagged, rasping, in direct contrast to her controlled, static postmodern environment.

Will smell, seduced by an endless procession of olfactory simulacra, succumb to its postmodern life, or will it - ever elusive - transcend its postmodern categorizations to remind us of our organic nature and even hint at a realm of the spirit? (Classen et al. 205)

As the audience leave the theatre, the smell, the odor, the aura remains, intangible, in the air. 


\section{Works Cited}

Auslander, Philip. Liveness. London: Routledge, 1999.

Benjamin, Walter. Illuminations, Essays and Reflections. Trans. Harry Zohn. New York: Schocken, 1968.

Classen, Constance, David Howes, and Anthony Synnott. Aroma: The Cultural History of Smell. London: Routledge, 1995.

Corbin, Alain. The Foul and The Fragrant: Odour and the Social Imagination. London: Picador, 1994.

Egervary, Barbra. "Another Con-Text." Acts of Passion: Sexuality, Gender and Performance. Ed. Nina Rapi and Maya Chowdry. New York: Harrington Park, 1998. 21-45.

Engen, Trygg. Odor Sensation and Memory. New York: Praeger, 1991.

Jones, Amelia. Body Art: Performing the Subject. Minneapolis: U of Minnesota P, 1998.

Phelan, Peggy. Unmarked: The Politics of Performance. London: Routledge, 1993.

Read, Alan. Theatre and Everyday Life. London: Routledge, 1993.

Vroon, Piet. Smell: The Secret Seducer. Trans. Paul Vincent. New York: Farrar, Straus and Giroux, 1997. 